\title{
BONITA OBCE AKO DETERMINANT ROZVOJA
}

\section{MUNICIPAL CREDITWORTHINESS AS A DETERMINANT OF DEVELOPMENT}

\section{PROF. ING. ELENA GáRSKA, CSC. ING. VERONIKA FERĹ́KKOVÁ}

\author{
Katedra verejnej správy a regionálneho rozvoja $\mid$ Dep. of Public Administration and Reg. Developmnet \\ Národohospodárska fakulta Faculty of National Economy \\ Ekonomická univerzita v Bratislave University of Economicsin Bratislava \\ $\triangle$ Dolnozemská cesta 1, 85235 Bratislava, Slovak Republic \\ E-mail:elena.zarska@euba.sk,veronika.fercikova@gmail.com
}

\begin{abstract}
Anotácia
Bonita obce vğeobecne zahน̌Ŕa hlavne dobrú kvalitu, vysokú hodnotu alebo povesŠ Predstavuje zhodnotenie a kumulované vyjadrenie kvalitatívnych a kvantitatívnych parametrov obce a môǵgme ju hodnotiŠ na úrovni celoğátnej, veăostnej a územnej. Je tvorená (podmienená) tromi aspektmi ï hospodárením obce pod $\mathbf{a}$ rozpol tu, majetkom obce, rozvojovými podmienkami obce. Pri jej stanovení je moğné vyuğŠ viacero metód ï naj! astejg̉e ide ofinan!̣ú a majetkovú analýzu. Hodnotenie sa interpretuje na ur! itej ġkále ï bonita zlá, nízka, problematická, dobrá, vysoká. Bonita má výraznú relevanciu k rozvojovým moǵnostiam a udrğateQosti rozvoja, k efektívnosti a stabilite fungovania obce a tieǵje východiskom pre komparáciu obcí benchmarkingovým prístupom. Príspevok na základe metodického postupu uplatnenému aj $v$ Leskej republike upraveného o výber relevantných ukazovateひ̆v k cie@ skúmania a rozvinutého o N̦alg̀e ukazovatele analyzuje a hodnotí bonitu 32 vybraných obcí SR. CieØ̆m skúmania je overenie dvoch závislosti: medzi vę̆os Šsu obce a hodnotou bonity; prosperitou územia a hodnotou bonity. Na základe ukazovate@̆v tvoriacich bonitu je moğié hodnotiŠaj kapacity obce pre miestny rozvoj.
\end{abstract}

\section{KŎílové slová}

bonita obce, segmenty bonity, miestny rozvoj

\section{Annotation}

Creditworthiness of municipality generally consists mainly of good quality, high value or reputation. It is an assessment and cumulative expression of qualitative and quantitative parameters of the municipality and it can be assessed at the national, territorial and size level. It is created (determined) by three aspects - management of the municipality under budget, municipal property and developing conditions of the municipality. During its determination, it is possible to use multiple methods - most often it concerns the financial and equity analysis. The rating is interpreted at a certain scale ï bad, low, problematic, good, high. Creditworthiness has a strong relevance to development opportunities and sustainable development, the efficiency and stable operation of the municipality and also provides the basis for comparing municipal benchmarking approach. The paper based on the methodology applied also in the Czech Republic, amended by the selection of relevant indicators for objective examination and developed by other indicators analyzes evaluates the creditworthiness of the 32 selected municipalities in Slovakia. The aim of the study is to verify the two dependencies: the size of the village and the value of creditworthiness; prosperity of area and value of assessments. Based on the indicators constituting the creditworthiness can also evaluate the capacity of municipalities for local development.

Key words municipality creditworthiness, segments of creditworthiness, local development 


\section{Úvod}

Pre miestne rozvojové procesy sa významným aktérom stala obec ako samosprávna územná jednotka disponujúca vlastným majetkom, finan!̣ nými zdrojmi, Qudským potenciálom a legislatívne vymedzenými kompetenciami. Túto pozíciu jej dali decentralizal né a demokratizal né procesy, ktorých výsledkom je posilnenie samosprávnosti riadenia, l’ o vğak predstavuje aj rastúcu zodpovednosŠ a právomoci spravovania zvereného územia. Zvládnutie danej úlohy je podmienené poznaním základných determinantov, url ujúcich schopnosŠa moǵnosŠ plne zabezpel ovaŚcelý rozsah výkonu pri poǵadovanej kvalite a efektívnosti. Jedným z takýchto determinantov je aj bonita obce. Prẹ o ju moǵno vymedziŠ ako determinant miestneho rozvoja? Bonita hodnotí stav obce na základe kvalitatívnych a kvantitatívnych parametrov, ktoré vyjadrujú a merajú finan! nú kondíciu obce (finan! ná bonita), kvalitu manaǵmentu aktív (majetková bonita) a hodnotia predpoklady rozvoja vo väzbe na vybavenosŠ obce a na aktivizáciu miestnych potenciálov (rozvojová bonita). Vg̉etky tieto faktory podmié́ujú zachovanie rozvoja a dosahovanie (zvyġovanie) konkurencieschopnosti obce.

\section{CieOa metódy}

Cie@̆m skúmania je na základe zvoleného metodického postupu vypoḷ ítaŠ bonitu obcí a zhodnotiŠ dosiahnuté výsledky vo vzŠahu k územnej a veăxostnej úrovne bonity. Pre skúmanie sú stanovené dve hypotézy: 1) existuje priama závislos ̌̌ medzi hodnotou bonity a veăos ̌̌su obce a 2) existuje priama závislos Š medzi hodnotou bonity a prosperitou územia. Pre dosiahnutie stanoveného cieă a overenie hypotéz sú pougóté viaceré vedecké metódy skúmania. Na základe guúdia zahranil ných a domácich zdrojov metódou historicko-logickou a abstrakcie bol ǵpecifikovaný metodický postup s výberom relevantných ukazovateQ̆v pre výpol et jednotlivých segmentov bonity obce a vođ̆ou bodovacej metódy pre hodnotenie jednotlivých ukazovateQ̆v. Metódy analýzy a komparácie umoǵnili vyhodnotiŠ obe stanovené závislosti cieă skúmania. Objektom skúmania je 32 obcí SR, pril om z kaǵdého vyğg̉eho územného celku sú 4 obce ( 8 VÚC) a obce reprezentujú jednu zo 4 veQ̆́ostných skupín: do 1000, do 5 000, do 20000 a nad 20000 obyvateQ̆v. Súl asne skupina 4 obcí je z jedného okresu VúC.

\section{Výsledky}

\section{Charakteristika bonity obce a spôsob jej merania}

Bonita obce je menej rozpracovaná kategóriou. Je jedným z najmladğm nástrojov, ktorý eg̉e neprenikol do beǵnej ḷ innosti a Ăslovníkañ obce. Niekedy je stotoǵŔRovaná s ratingom obce, ktorý je známejğ, pouǵivanejğ nástroj ï hodnotiaci schopnosડ̌ uhrádzaŠ svoje záväzky v krátkodobom a dlhodobom horizonte, je ur! itou Ǎznal kouñ solventnosti a dôveryhodnosti obce. Jeho význam treba vidieŠ $\mathrm{v}$ prvom rade $\mathrm{v}$ podobe (marketingového) nástroja zameraného na potenciálnych investorov a na udróninie si existujúcich podnikateQ̄v, no má svoju hodnotu aj ako informaḷ ný nástroj pre potenciálnych obyvateQ̆v. NezanedbateĞá je jeho úlohu politického nástroja predstaviteQ̆v miest a obcí v predvolebnom období pri znovu uchádzaní sa o volené posty. Bonita obce je obsahovo g̈rg̈e koncipovaná, umoǵḱuje hodnotiŠ komplexne situáciu obce na základe troch jej súl asti ï finan! nej bonity, majetkovej a rozvojovej bonity. Jednou z komplexnejğch ǵúdií o bonite je práca autorov Halásek a kol. (2002). Táto ğúdia v podmienkach L R bola základom rozsiahlejg̉eho výskumu autorov Halásek a kol. (2005). Obe ġúdie motivovali výskum prezentovaný v príspevku. Na súbore vybraných 32 obcí sa realizoval výpoḷ et bonity obce. Hodnota celkovej bonity je súl tom hodnôt finan! nej, majetkovej a rozvojovej bonity. Kaǵlý segment bonity umoǵŔuje na báze pouğitých ukazovateQ̆v vypovedaŠ o slabých miestach, rezervách, ale aj silných stránkach, ktoré treba obcou udróaš Ukazovatele sú zvolené tak, aby uǵ svojou konğrukciou hodnotili efektívnosŠ narábania s finan! nými prostriedkami finan! nou silou a kapacitou obce (G̣árska a kol., 2007; Peková, 2011) a 
vyuğ́vanie a zhodnocovanie majetku (Papúncová a Baláǵová, 2006). Vybrané ukazovatele a ich výpoḷ et je v tabuQ̆e 1.

Tab. 1: Ukazovatele finan! nej a majetkovej bonity

\begin{tabular}{|c|c|}
\hline UkazovateC pre finan!̣ nú bonitu & Výpol et \\
\hline DaRová sila & daŔové príjmy/obyvate $\bar{O}$ \\
\hline Finan! ná sila & (daŔové príjmy + beǵné granty a transfery)/obyvateC \\
\hline Miera sebestal nosti (príjmov) 1 & vlastné príjmy/celkové príjmy \\
\hline Miera sebestal nosti (príjmov) 2 & (vlastné príjmy+beǵné granty a transfery)/celkové príjmy \\
\hline Miera samofinancovania & vlastné príjmy/beǵné výdavky \\
\hline Dlhová kapacita & beğné príjmy/(beǵné výdavky + splácanie úverov) \\
\hline UkazovateŌpre majetkovú bonitu & Výpol et \\
\hline hrubá majetková sila obce & Celková hodnota majetku/obyvateC \\
\hline I̦ istá majetková sila obce & (celková hodnota majetku -záväzky**)/obyvateC \\
\hline hrubý príjmový efekt majetku & vlastné príjmy/ celková hodnota majetku \\
\hline | istý príjmový efekt majetku & príjmy z majetku***/ celková hodnota majetku \\
\hline reproduk! ná schopnosŚbce & kapitálové príjmy/ celková hodnota majetku \\
\hline reproduk! ná sila obce & kapitálové výdavky/ celková hodnota majetku \\
\hline
\end{tabular}

Výpoḷ et finan! nej a majetkovej bonity sa realizoval na týchto 12 ukazovateØ̆v, ktoré boli vypoḷ ítané pre roky 2010,2011 a 2012, z nich sa urobil aritmetický priemer a kaǵdý ukazovateŎ obce bol reprezentovaný týmto priemerom. Pre stanovenie bonity bolo potrebné prideliŠ bodové hodnotenie na základe tabuă 2. Metodika je závislá od toho, !̣ i sa poḷ íta bonita na územnej alebo veQ̆ostnej úrovni (viṆ niğğe).

Tab. 2: Bodové hodnotenie odchýliek od strednej úrovne

\begin{tabular}{|r|c|}
\hline-5 & menej neǵ $50 \%$ priemeru územia \\
\hline-4 & $50 \%-59 \%$ priemeru územia \\
\hline-3 & $60 \%-69 \%$ priemeru územia \\
\hline-2 & $70 \%-79 \%$ priemeru územia \\
\hline-1 & $80 \%-89 \%$ priemeru územia \\
\hline 0 & $90 \%-99 \%$ priemeru územia \\
\hline & priemer území \\
\hline 1 & $100 \%-109 \%$ priemeru územia \\
\hline 2 & $110 \%-119 \%$ priemeru územia \\
\hline 3 & $120 \%-129 \%$ priemeru územia \\
\hline 4 & $130 \%-139 \%$ priemeru územia \\
\hline 5 & $140 \%-149 \%$ priemeru územia \\
\hline
\end{tabular}

Zdroj: Halásek, Birner, Legátová 2005, s. 21

Pre hodnotenie rozvojovej bonity boli vybrané ukazovatele, s ktorými narábala !̣ eských autorovgúdia z roku 2005 s úpravami a doplnením o N̦alg̈e, ktoré sú relevantné pre hodnotenie podmienok rozvoja. Ing̣piráciou mohla byŠ aj ġúdia ĂCreditworthiness-Handbook-for-Municipalitiesñ tá vğkk kládla dôraz na ukazovatele vonkajğej bonity vrátane demografického vývoja. Vybraných 10 ukazovateăv (tabuQ̆a 3) zodpovedá v podmienkach SR vlastným kompetenciám obcí (vnútorná bonita) a druhá skupina ukazovate@̆v (vonkajg̉a bonita) preneseným kompetenciám, resp. hodnotí vybavenosડ̌ ktorú obce môǵu len |̣ iastol ne ovplyvŔovaS (spolu so gátnou správou), resp. vytváraŠ podmienky a iniciovaŠs N̦alğmi aktérmi v území. 
Tab. 3: Ukazovatele rozvojovej bonity

\begin{tabular}{|c|c|c|c|}
\hline & UkazovateC & Zloǵky ukazovateāa & Bodová hodnota \\
\hline \multirow{7}{*}{$\begin{array}{l}\text { Vnútorná } \\
\text { rozvojová } \\
\text { bonita }\end{array}$} & \multirow[t]{2}{*}{ Územný plán } & Existuje vôbec? & $1 \mathrm{~b}$. \\
\hline & & $\begin{array}{l}\text { Je aktuálny? (nemá viac ako 5r alebo } \\
\text { nie je potrebné ho meniŠ) }\end{array}$ & $2 \mathrm{~b}$. \\
\hline & $\begin{array}{l}\text { Strategické } \\
\text { dokumenty }\end{array}$ & koQ̄o? & 1 ak PHSR max 5 ak aj iné b. \\
\hline & \multirow[t]{2}{*}{$\begin{array}{l}\text { Spolupráca s inými } \\
\text { subjektmi na rozvoji }\end{array}$} & $\begin{array}{l}\text { Existuje spolupráca s obcami (reálne } \\
\text { dokumenty)? }\end{array}$ & $1 \mathrm{~b}$. za projekt, max. $5 \mathrm{~b}$. \\
\hline & & $\begin{array}{l}\text { Existuje spolupráca s podnikateŌni } \\
\text { (reálne projekty, aktivity)?-klástre } \\
\text { (vínne cesty, kúpeQ̆ý klaster, } \\
\text { priemyselný park, podnikateQ̆ký } \\
\text { inkubátor, MASky, }\end{array}$ & 1 b. za projekt, $\max .5 \mathrm{~b}$. \\
\hline & G̦iadosti o projekty & $\begin{array}{l}\text { Úspeğné ǵiadosti o dotácie (pol as } 3 \\
\text { rokov) }\end{array}$ & $1 \mathrm{~b}$. za projekt, $\max 5 \mathrm{~b}$. \\
\hline & $\begin{array}{l}\text { Významná znal ka } \\
\text { (branding) }\end{array}$ & Napr. Osrblie Ï biatlon & $\begin{array}{l}1 \text { b. max } 3 \text { body (podQ } \\
\text { významnosti) }\end{array}$ \\
\hline \multirow{14}{*}{$\begin{array}{l}\text { Vonkajğa } \\
\text { rozvojová } \\
\text { bonita }\end{array}$} & \multirow{3}{*}{$\begin{array}{l}\text { Vybavenos } \\
\text { technickou } \\
\text { infrağruktúrou }\end{array}$} & Vodovod & $1 \mathrm{~b}$. \\
\hline & & Kanalizácia napojená na L্OV & $3 \mathrm{~b}$. \\
\hline & & Plynofikácia & $2 \mathrm{~b}$. \\
\hline & \multirow{7}{*}{$\begin{array}{l}\text { VybavenosŠ } \\
\text { sociálnou } \\
\text { infraǵruktúrou }\end{array}$} & Materská ǵkola & $1 \mathrm{~b}$. \\
\hline & & Základná ğkola (1. stupeR) & $1 \mathrm{~b}$. \\
\hline & & Základná ğkola (2. stupeR) & $2 \mathrm{~b}$. \\
\hline & & Zdravotné zariadenie ambulantné & 1b. $\max 5 \mathrm{~b}$. \\
\hline & & zdravotné zariadenie pobytové - roḷ né & 1b. max 5b. \\
\hline & & $\begin{array}{l}\text { zdravotné zariadenie pobytové - } \\
\text { týǵdenne }\end{array}$ & 1b. $\max 5 b$. \\
\hline & & Zdravotné zariadenie terénne & 1b. $\max 5 b$. \\
\hline & Kultúrna vybavenos $\tilde{S}$ & kultúrny dom, kino, divadlo & $1 \mathrm{~b}$. za kaǵdé zariadenie max $3 \mathrm{~b}$. \\
\hline & Významné podniky & Podniky s viac ako 10 zamestnancami & 1 bod za podnik, max. $5 \mathrm{~b}$. \\
\hline & \multirow[t]{2}{*}{ Dopravná poloha } & $\begin{array}{l}\text { vzdialenosŠod krajského mesta (v } \\
\text { min.) }\end{array}$ & $\begin{array}{ll}\text { do } 15 \text { minút } & +3 \text { body } \\
\text { do } 30 \text { minút } & +2 \text { body } \\
\text { do } 45 \text { minút } & +1 \text { bod } \\
\text { do } 60 \text { minút } & 0 \text { bodov } \\
\text { do } 90 \text { minút } & \text { ï } 3 \text { body } \\
\text { do } 120 \text { minút } & \text { i } 5 \text { bodov }\end{array}$ \\
\hline & & Bonus za ǵeleznicu (funk! nú traś) & $1 \mathrm{~b}$. \\
\hline
\end{tabular}

Zdroje pre výpoḷ ty: územné plány, PHSR, webové stránky miest a obcí, www.mapy.sk, www.vsportal.sk

Zdroj: spracované podă Halásek ï Birner ï Legátová 2005, s. 33 + doplnené autorkami

\section{Hodnotenie bonity na územnej úrovni a overenie prvej hypotézy}

Porovnávanie a hodnotenie bonity obce v územnom celku (okrese) je moǵné realizovaŠ po výpoḷ te priemernej hodnoty bonity okresu. Táto sa vypoḷ íta pre jednotlivé súl asti (finan!̣ nú, majetkovú a rozvojovú) na základe hodnôt ukazovateŎov obcí. Pre kaǵdý ukazovateŎ (22 ukazovateQ̆v) sa vypoḷ íta priemerná hodnota (vypolítaním priemeru za 4 obce reprezentujúce okres) a s touto hodnotou je porovnávaná hodnota ukazovateă obce s pridelením bodov na základe tabuăyy 3. Získané body sa ș ítajú pre jednotlivé bonity. Súl et finan! nej, majetkovej a rozvojovej bonity tvorí celkovú hodnotu bonity obce. Pri výpoḷ te je moǵné niektoré ukazovatele, resp. niektorú z bonít bonifikovaŠ vyğggou váhu alebo aj váhu zníǵiš V uvádzanom prístupe je zníǵená váha rozvojovej bonity na 0,6 , aby 10 ukazovateQ̆v rozvojovej bonity bolo vo váhe so 6 ukazovateŎni finan! nej a aj majetkovej bonity. Z hodnôt celkovej bonity sa urobí poradie. 
Tab. 4: Územná bonita obcí

\begin{tabular}{|c|c|c|c|c|c|c|c|c|}
\hline 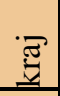 & $\frac{0}{0}$ & 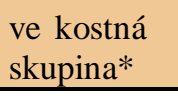 & obec/mesto & $\begin{array}{c}\text { Finan! ná } \\
\text { bonita }\end{array}$ & $\begin{array}{c}\text { Majetková } \\
\text { bonita }\end{array}$ & $\begin{array}{c}\text { Rozvojová } \\
\text { bonita** }\end{array}$ & $\begin{array}{c}\text { Celková } \\
\text { bonita }\end{array}$ & Poradie \\
\hline \multirow{4}{*}{ 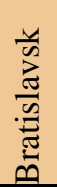 } & \multirow{4}{*}{ 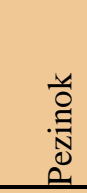 } & do 1000 & Dubová & 4 & 10 & $-13,2$ & 0,8 & 3 \\
\hline & & do 5000 & Slovenský Grob & -4 & -14 & $-4,8$ & $-22,8$ & 4 \\
\hline & & do 20000 & Modra & 3 & -5 & 8,4 & 6,4 & 2 \\
\hline & & nad 20000 & Pezinok & 0 & -2 & 10,8 & 8,8 & 1 \\
\hline \multirow{4}{*}{ 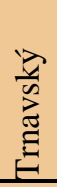 } & \multirow{4}{*}{ 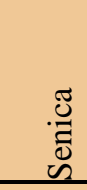 } & do 1000 & Plavecký Peter & 8 & 4 & $-16,2$ & $-4,2$ & 2 \\
\hline & & do 5000 & Jablonica & -3 & -13 & -6 & -22 & 4 \\
\hline & & do 20000 & Ġagín-Stráǵe & -1 & 6 & $-9,6$ & $-4,6$ & 3 \\
\hline & & nad 20000 & Senica & -1 & 5 & 14,4 & 18,4 & 1 \\
\hline \multirow{4}{*}{$\begin{array}{l}\frac{\lambda}{n} \\
. \Xi \\
0 \\
0\end{array}$} & \multirow{4}{*}{ 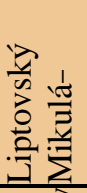 } & do 1000 & BeŔadiková & -6 & -14 & -15 & -35 & 4 \\
\hline & & do 5000 & Vaǵec & 0 & 7 & $-16,8$ & $-9,8$ & 3 \\
\hline & & do 20000 & Dolný Kubín & 2 & 0 & 8,4 & 10,4 & 2 \\
\hline & & nad 20000 & Liptov. Mikuláġ & 3 & 3 & 20,4 & 26,4 & 1 \\
\hline \multirow{4}{*}{ 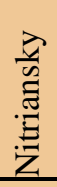 } & \multirow{4}{*}{ 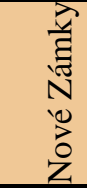 } & do 1000 & Podhájska & 7 & 16 & $-10,2$ & 12,8 & 1 \\
\hline & & do 5000 & Palárikovo & -13 & -4 & 3,6 & $-13,4$ & 4 \\
\hline & & do 20000 & Ġúrovo & 6 & -10 & 5,4 & 1,4 & 3 \\
\hline & & nad 20000 & Nové Zámky & 2 & -6 & 10,8 & 6,8 & 2 \\
\hline \multirow{4}{*}{ 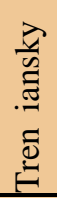 } & \multirow{4}{*}{ 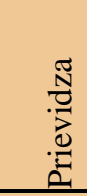 } & do 1000 & Kocurany & -5 & 21 & $-13,8$ & 2,2 & 2 \\
\hline & & do 5000 & Bojnice & -1 & -5 & 3,6 & $-2,4$ & 3 \\
\hline & & do 20000 & Handlová & -2 & -6 & 10,8 & 2,8 & 1 \\
\hline & & $\operatorname{nad} 20000$ & Prievidza & 2 & -17 & 3,6 & $-11,4$ & 4 \\
\hline \multirow{4}{*}{ 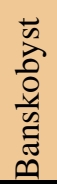 } & \multirow{4}{*}{ 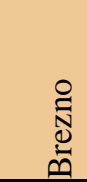 } & do 1000 & Horná Lehota & 10 & -9 & $-10,8$ & $-9,8$ & 3 \\
\hline & & do 5000 & НeQ̆а & -7 & 3 & 0 & -4 & 2 \\
\hline & & do 20000 & Lierny Balog & 0 & -9 & $-9,6$ & $-18,6$ & 4 \\
\hline & & nad 20000 & Brezno & -2 & -1 & 11,4 & 8,4 & 1 \\
\hline \multirow{4}{*}{ 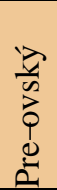 } & \multirow{4}{*}{ 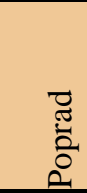 } & do 1000 & Gerlachov & -5 & -14 & $-5,4$ & $-24,4$ & 4 \\
\hline & & do 5000 & Vysoké Tatry & 8 & -3 & 6,6 & 11,6 & 1 \\
\hline & & do 20000 & Svit & -5 & 5 & $-1,2$ & $-1,2$ & 3 \\
\hline & & $\operatorname{nad} 20000$ & Poprad & 5 & -5 & 8,4 & 8,4 & 2 \\
\hline \multirow{4}{*}{ 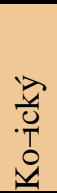 } & \multirow{4}{*}{$\begin{array}{l}\overrightarrow{0} \\
\frac{0}{0} \\
0\end{array}$} & do 1000 & VeQ̆é Ozorovce & 0 & -2 & $-16,2$ & $-18,2$ & 3 \\
\hline & & do 5000 & Lierna nad Tisou & 0 & -15 & $-7,8$ & $-22,8$ & 4 \\
\hline & & do 20000 & Sel ovce & 2 & 7 & 8,4 & 17,4 & 2 \\
\hline & & $\operatorname{nad} 20000$ & Trebiğbv & 2 & 10 & 21,6 & 33,6 & 1 \\
\hline
\end{tabular}

*veQtostné skupiny sú vytvorené na základe pol tu obyvateQ̄ov

**rozvojová bonita je poḷ ítaná na základe 10 ukazovateQ̆v a jej váha bolo zníǵená koeficientom 0,6 na úroveR váhy finan! nej a majetkovej, ktoré sú poḷ ítané na základe 6 ukazovateQ̆v.

Zdroj: vlastné spracovanie

Na základe dosiahnutých výsledkov a poradí obcí (Tabuăa 4) je moǵné kong̉atovaŠ ǵe hypotéza 1

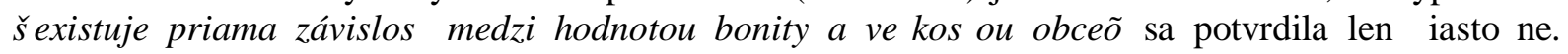
$\mathrm{V}$ piatich okresoch má najvyğgiu bonitu najväl ġe (okresné) mesto, no v troch okresoch tomu tak nie je. V okrese Nové Zámky reprezentujúceho Nitriansky kraj dosiahla najvyğgiu hodnotu obec Podhájska (známa termálnou vodou), ktorá má z obcí okresu najvyg̣g̉u finan! nú aj majetkovú bonitu a je treba konǵatovaŠ ǵe kúpalisko aj s viacerými obsluğnými a ubytovacími zariadeniami je v obecnom vlastníctve, liǵe je tu dobré zhodnocovanie a manaǵment majetku. V okrese Prievidza Trenl ianskeho kraja má najvyğgiu hodnotu mesto Handlová a okresné mesto Prievidza je aǵ na 4. mieste, na ktoré ho stiahla majetková bonita. Hypotéze nezodpovedá ani situácia v okrese Poprad za Preg̉ovský kraj, kde veQ̆kos ̌̌ou aǵ tretie mesto Vysoké Tatry má najvyğg̈u bonitu, ! o dosiahlo vyğğou finan! nou bonitou ako okresné mesto Poprad. Výsledky dokumentujú eg̉e jednu skutol nosŠ ǵe 
v dvoch okresov ï Liptovský Mikuláǵ a Poprad má najmeng̉a obec (do 1000 obyvateQ̆v) najhorg̈u hodnotu bonity (BeŔadiková a Gerlachov), pril om vg̉etky hodnoty ich bonít sú záporné.

\section{Hodnotenie bonity na veČxostnej úrovni a overenie druhej hypotézy}

Porovnávanie a hodnotenie bonity obcí v rovnakej veăkostnej skupine tzv. veăkostná bonita predstavuje korektnejğ prístup, pretoǵe obce rovnakej veăkostnej skupiny zdieQ̆jú viacero podobných znakov ï mechanizmy financovania obcí (podielové dane, dotácie) majú väl ġnou zabudované veC̆ostné kritériá, resp. kritérium je poḷ et obyvateQ̆v, tieǵ daŔové systémy sú kodifikované od poḷ tu obyvateŎov (sadza dane z nehnuteĞostí), ako aj hodnota (cena, nájom) nehnuteăostí sa odvíja od veQ̆kosti obce, podobným znakom je veăkrát infrağruktúrna poddimenzovanosડ̌ malých obcí, veQ̆́os Šrozpoḷ tu determinujúca moǵnosŠ prijímania úverov, grantov a pod.

Výpol et základu pre stanovenie bonity obce podă veQ̆ostných skupín je analogický $\mathrm{s}$ predchádzajúcim postupom, no $\mathrm{v}$ tomto prípade základ pre výpoḷty jednotlivých bonít sú spriemerované hodnoty 22 ukazovateQ̆v obcí jednej veŎostnej skupiny (8 obcí), kde pre kaǵdý ukazovateŎ sa vypoḷíta priemerná hodnota a tá je postupne podQ jednotlivých ukazovateQ̄v porovnávaná odchýlkou od strednej úrovne a podQ̆ percentuálnej veQ̆osti tejto odchýlky sa pridelí príslug̉ý pol et bodov (tabuăa 3). Na základe hodnôt finan! nej, majetkovej a rozvojovej bonity sa vypoḷ íta celková bonita a priradí poradie (viṆ tabuQ̆a 5).

Bonita vo veQ̆xostných skupinách umoǵRuje obciam/mestám sa identifikovaŠ v rámci svojej skupiny, nielen zhodnotiŠ svoju pozíciu, ale vidieŠ aj ktorá súl as ̌̌ bonity Ăspôsobilañ získané poradie a kde treba upriamiŠ pozornosŠ v N̦alg̈ej ! innosti. Prezentované výsledky ukazujú, ǵe najvyğgie bonity vo svojej veQ̆kostnej skupine dosiahli ï Podhájska, Vysoké Tatry, Svit a Poprad. Obec Podhájska a mesto Vysoké Tatry mali najvyğg̉u bonitu aj v rámci svojho územia okresu, !̣o svedḷí o tom, ǵe dobre manaǵujú svoje finan! né prostriedky a majetok a zhodnocujú svoj rozvojový potenciál. V súvislosti s druhou hypotézou Ă existuje priama závislos Š medzi hodnotou bonity a prosperitou územiañ, ak by sme prosperitu územia (vyğgieho územného celku) odvíjali od hodnôt HDP na obyvate@̆, miery nezamestnanosti, hustoty podnikateQ̆kej aktivity, miery sociálnej odkázanosti apod. a dali do vzŠahu k poradiu obcí/miest na základe celkovej bonity v tabuQ̆e 5, tak je moǵné konğatovaŠ ǵe sa hypotéza nepotvrdila (najniğǵ súl et poradí majú obce Preǵovského kraja, potom nasledujú Tren! ianskeho kraja a Nitrianskeho, pril om obce Bratislavského a Banskobystrického kraja majú rovnaký súl et poradí na ġvrtom aǵ piatom mieste a na poslednom mieste sú obce Koğckého kraja. V hodnotení sociálno ï ekonomickej úrovne je pritom Bratislavský kraj na prvom mieste a na druhom konci poradia sú okrem Kog̈ického kraja aj kraj Preġovský a Banskobystrický. Konġatovanie sa opiera o údaje základných charakteristík regiónov Gatistického úradu SR. 
Tab. 5: Ve đ̆ostná bonita obcí

\begin{tabular}{|c|c|c|c|c|c|c|}
\hline $\begin{array}{l}\text { VeQ̆ostná } \\
\text { skupina* }\end{array}$ & Obec/mesto & $\begin{array}{c}\text { Finan! ná } \\
\text { bonita }\end{array}$ & $\begin{array}{c}\text { Majetková } \\
\text { bonita }\end{array}$ & $\begin{array}{c}\text { Rozvojová } \\
\text { bonita** }\end{array}$ & $\begin{array}{c}\text { Celková } \\
\text { bonita }\end{array}$ & Poradie \\
\hline \multirow[t]{8}{*}{ do 1000} & Dubová & 1 & 1 & 4 & 6 & 4 \\
\hline & Plavecký Peter & 1 & 4 & 1 & 6 & 4 \\
\hline & BeŔadiková & -9 & -17 & -7 & -33 & 7 \\
\hline & Podhájska & 1 & 8 & 9 & 18 & 1 \\
\hline & Kocurany & -5 & 19 & -5 & 9 & 2 \\
\hline & Horná Lehota & 8 & -13 & 13 & 8 & 3 \\
\hline & Gerlachov & -1 & -13 & -4 & -18 & 5 \\
\hline & VeQ̄xé Ozorovce & -3 & -3 & -16 & -22 & 6 \\
\hline \multirow[t]{8}{*}{ do 5000} & Slovenský Grob & 0 & -16 & 1 & -15 & 4 \\
\hline & Jablonica & 0 & -12 & -6 & -18 & 6 \\
\hline & Vaǵec & 2 & -4 & -20 & -22 & 7 \\
\hline & Palárikovo & -10 & -11 & 4 & -17 & 5 \\
\hline & Bojnice & -1 & 2 & 9 & 10 & 2 \\
\hline & НеQ̄ळa & -6 & 0 & 9 & 3 & 3 \\
\hline & Vysoké Tatry & 14 & 4 & 10 & 28 & 1 \\
\hline & Liena nad Tisou & 2 & -13 & -14 & -25 & 8 \\
\hline \multirow[t]{8}{*}{ do 20000} & Modra & 4 & -2 & -1 & 1 & 3 \\
\hline & Ġagín-Stráğe & -1 & 7 & -19 & -13 & 6 \\
\hline & Dolný Kubín & 1 & -8 & 5 & -2 & 4 \\
\hline & Ġúrovo & 2 & -9 & 8 & 1 & 3 \\
\hline & Handlová & 1 & 0 & 13 & 14 & 2 \\
\hline & Lierny Balog & -1 & -7 & -10 & -18 & 7 \\
\hline & Svit & 1 & 18 & 4 & 23 & 1 \\
\hline & Sel ovce & -1 & 3 & -8 & -6 & 5 \\
\hline \multirow[t]{8}{*}{ nad 20000} & Pezinok & -1 & -6 & -5 & -12 & 5 \\
\hline & Senica & -2 & 13 & 4 & 15 & 2 \\
\hline & Liptov. Mikuláç & 2 & -1 & 4 & 5 & 3 \\
\hline & Nové Zámky & -2 & -7 & -3 & -12 & 5 \\
\hline & Prievidza & 1 & -16 & -1 & -16 & 6 \\
\hline & Brezno & -3 & 6 & 2 & 5 & 3 \\
\hline & Poprad & 9 & 8 & 4 & 21 & 1 \\
\hline & Trebiğbv & -2 & 6 & -1 & 3 & 4 \\
\hline
\end{tabular}

*veQ̊́ostné skupiny sú vytvorené na základe pol tu obyvate@̈o

**rozvojová bonita je pol ítaná na základe 10 ukazovateQ̆v a jej váha bolo zníǵená koeficientom 0,6 na úroveŔ váhy finan! nej a majetkovej, ktoré sú pol ítané na základe 6 ukazovateQ̆v.

Zdroj: vlastné spracovanie

Výsledky prezentované v tabuđ̆ách 4 a 5 umoǵŔujú formulovaŠniekoăo !̣i iastkových záverov:

- najlepg̈e hodnoty bonity dosahovali obce podQ̆ ukazovateQ̆v finan! nej bonity,

- najhorg̈e výsledky mali obce do 1000 obyvateăv v rozvojovej bonite, ! o vyplýva jednak z ich infrağruktúrnej poddimenzovanosti a zlou dopravnou polohou (vonkajg̈a bonita), ! o vğak moǵno aj v podmienkach malých obcí (!̣ iastoḷ ne) kompenzovaŠzlepǵením hodnôt vnútornej rozvojovej bonity,

- veăos ̌̌obce nemusí byŠdeterminant veQ̆osti bonity ï závislosŠsa potvrdila len u kategórie obcí nad 20000 obyvateQ̆v, ktorú reprezentovali okresné mestá ï tie sú uǵ dlhé obdobie spádovými mestami, administratívnymi centrami s koncentráciou ekonomických aktivít a dobrou dopravnou dostupnosŠou ï pozície ostatných obcí sa môǵu odvíjaŠ od schopnosti a kvality vyuğivania (zhodnocovania) svojich potenciálov, ! ím Ămaléñ nemusí byŠnízke alebo zlé,

- dve vybrané obce ï Podhájska a Vysoké Tatry dosiahli najvyğgiu bonitu tak v území ako aj vo svojej veQ̆ostnej skupine, ! o pre ostatné obce môǵe predstavovaŠ ur!̣itý benchmark pre porovnávanie,

- nepreukázala sa ani závislosŠ hodnôt bonity obce od prosperity územia kraja (sociálnoekonomickej úrovne), ! o je dané ukazovateŎni, z ktorých sa bonita pol íta. Vybraný súbor 22 
ukazovateQ̆v Ănie je citlivýñ na ekonomické a sociálne charakteristiky územia (produk!̣ nosડ̌, nezamestnanosŠ, sociálna odkázanosŠ, ...), ale hodnotí kvalitu a efektívnosŠfungovania obce.

\section{Záver}

Prezentovaný výskum je realizovaný na súbore 32 obcí SR, ktoré nepredstavujú reprezentatívnu vzorku, ! o podmieŔuje aj relevantnosŠ niektorých záverov. Predstavuje vğłk dobré východisko pre N̦alğe analýzy, resp. aj formulovania odporúl aní pre hodnotenie kvality a efektívnosti fungovania obcí. Dosiahnutá bonita obcí môǵe slúǵiš pre predstaviteQ̆v vybraných obcí ako hodnotiaci nástroj, z ktorého je moğné odvodiŠ slabé miesta $\mathrm{v}$ narábaní s finan! nými prostriedkami, vyuğ́vaní majetku ako aj elimináciou nedostatol ných vnútorných a vonkajğch predpokladov zvyğovaš svoju konkurencieschopnosŠ a zachovávaŠ udróateăný rozvoj. Porovnávanie svojich hodnôt bonity, resp. ukazovateQ̆v, ktoré ju tvoria, s inými obcami umoǵŔuje implementovaš Ănajlepg̉u praxñ v prospech svojich ob! anov. Z tohto pohQ̆du je bonita obce hodnotiacim nástrojom aj pre ob!̣ ana, pretoǵe mu umoǵ́uje vidieŠ pozíciu svojej obce ako výsledok kvality práce ním volených zástupcov.

\section{Literatúra}

[1] HALÁSEK, D., PILNÝ, J., TOMÁNEK, P., (2002). Ur!̣ ovaní bonity obcí. Ostrava: Vysoká g̉kola bánska Ï Technická univerzita. ISBN 80-248-0159-0

[2] HALÁSEK, D., BINER, J., LEGÁTOVÁ, J., (2005). PŚípadová studie ï Ekonomický potenciál obcí. PŚrov Ï Brno: Ministerstvo pro místní rozvoj L R Ï WB 29-04.

[3] Handbook for municipalities., (2009). <http://www.ppiaf.org/sites/ppiaf.org/files/publication/Creditworthiness-Handbook-forMunicipalities.pdf $>$.

[4] Network od Associations of Local Authorities of South-East Europe. Guidelines on Local Government Borrowing and Recent Developments in South East Europe. [online]. Dostupné z: <http://www.nalas.eu/borrowing/4_1.html>.

[5] PAPCÚNOVÁ, V., BALÁG̣OVÁ, E., (2006). Majetok obcí. Nitra: Slovenská akadémia. poQ̆ohospodárskych vied. ISBN 80- 89162-19-3

[6] PEKOVÁ, J., (2011). Finance územní samosprávy. Praha: Wolters Kluwer. ISBN 978-80-7357-614-1.

[7] G̦ÁRSKA, E. A KOL., (2007). Komunálna ekonomika a politika. Bratislava : VydavateQ̆tvo Ekonóm. ISBN 978-80-225-2293-9.

Príspevok bol spracovaný v rámci grantu VEGA !̣.1/1319/12 Optimálna samosprávna jednotka ï kompetentný aktér a efektívny správca veci verejných. 